JIPFRI, Vol. 2 No. 1

Halaman: 14-20

Mei 2018
JIPFRI (Jurnal Inovasi Pendidikan Fisika dan Riset IImiah)

DOI: 10.30599/jipfri.v2i1.147

\title{
Perkembangan Eksperimen Fisika Ditinjau dari Filsafat Sains
}

\author{
Ike Festiana \\ Universitas Nahdlatul Ulama Lampung \\ Jl. Hanafiah Lintas Timur, Mataram Marga, Kec. Sukadana, Kab. Lampung Timur \\ ‘E-mail: ikefestiana@unulampung.ac.id
}

\begin{abstract}
Abstrak
IImu pengetahuan semakin lama semakin berkembang dari waktu ke waktu begitu juga dengan eksperimen. Eksperimen berkembang pada abad ke tujuh belas. Sebelum abad ke tujuh belas informasi mengenai perkembangan dunia diperoleh dengan menghubungkan peran epistemologis terkemuka. Eksperimen diartikan sebagai program terencana untuk menguji hipotesis dengan menyediakan bukti-bukti empiris terhadap sekelompok subyek. Sains merupakan suatu proses untuk mencari kebenaran. Kegiatan dalam mencari kebenaran melibatkan serangkaian metode saintifik yang salah satunya adalah eksperimen. Karakteristik perkembangan sejarah periode fisika terdiri dari periode satu hingga periode lima. Pada periode satu ditandai dengan belum adanya eksperimen yang sistematis dan kebebasan dalam mengadakan percobaan. Pada periode dua metoda eksperimen sudah dapat dipertanggungjawabkan, diakui dan diterima sebagai persoalan ilmiah. Pada periode ketiga perkembangan penyelidikan semakin pesat lagi, pertumbuhan dan perkembangan Fisika klasik yang meletakkan dasar Fisika kuantum yang terkenal di abad sekarang. Periode keempat ditandai adanya fenomena-fenomena mikroskopis yaitu fenomena yang tidak dapat dilihat langsung disebut juga periode The Old Quantum Mechanics. Periode kelima dikenal dengan Teori baru "Teori Kuantum Mekanika Baru (The New Quantum Mechanics)".
\end{abstract}

Kata kunci: eksperimen, sains, perkembangan sejarah fisika

\begin{abstract}
Scientific knowledge as well as experiment keeps on growing every day. Experiments flourished in the seventeenth century. Previously, information about world development was obtained by connecting the roles of prominent epistemology. Experimentation is defined as a planned program for restoring hypotheses by providing empirical evidence to people. Science is a process of seeking the truth. Activities in finding the truth involves a series of scientific method including experiment. The development of physics history is divided into five periods. Period one is indicated by the absence of systematic and independent experiment. In period two, experimental methods had been accountable, and well accepted as a scientific issue. In period three, (investigations developed more rapidly when classical physics development began to be foundation of current famous quantum physics). Period four which is called The Old Quantum Mechanics is indicated by the invention of microscopic phenomena. Period five is well known by the emergence of new quantum mechanics theory.
\end{abstract}

Keywords: experiments, science, the development of the history of physics

\section{PENDAHULUAN}

Perkembangan ilmu pengetahuan manusia terus mengalami perkembangan dan berevolusi dari waktu ke waktu. Termasuk eksperimen dan penelitian. Eksperimen menjadi subyek perdebatan di kalangan sejarawan ilmu pengetahuan modern. Eksperimen yang muncul pada abad ketujuh belas merupakan pandangan yang diterima sebagai bagian dari era diskontinuitas radikal dalam metode dan praktek-praktek menyelidiki alam.

Francis Bacon (1561-1626), Galileo Galilei (1564-1642), Robert Boyle (1627-1691), dan Isaac Newton (1642-1727) adalah para filsuf yang mempraktekkan dan mengembangkan percobaan. Tidak terjadi upaya yang ekstensif dan sistematis untuk memahami dan memanipulasi alam dengan cara eksperimen sebelum abad ke tujuh belas. Saat sebelum revolusi ilmiah, cara memperoleh informasi tentang dunia alam lebih dominan tanpa bantuan observasi. Sejalan dengan filsafat alam Aristoteles, yang dihubungkan 
dengan peran epistemologis terkemuka untuk pengalaman yang terjadi setiap hari. eksperimen "interogasi" alam yang aktif mengintervensi kerja alam dan dengan memanipulasi faktanya menandai abad ketujuh belas (Jalius, 2011).

Sains berasal dari bahasa latin yaitu scientia yang berarti "pengetahuan" (Fisher, 1975), atau dalam bahasa inggris berasal dari kata science. Sains menurut hakikatnya adalah suatu cara untuk memperoleh pengetahuan baru yang berupa produk, proses, dan sikap ilmiah. Hakikat IPA merupakan makna alam dan berbagai fenomena/perilaku/karakteristik yang dikemas menjadi sekumpulan teori maupun konsep melalui serangkaian proses ilmiah yang dilakukan manusia. Sains diartikan sebagai semua pengetahuan yang diperoleh dengan metode ilmiah (Herlanti, 2014).

Sains diartikan sebuah proses dalam usaha pencarian kebenaran dan usaha yang dimaksud diperoleh dengan metode ilmiah (metode saintifik). Metode saintifik adalah proses ini melibatkan serangkaian kegiatan, yang terdiri dari: 1) Identifikasi masalah atau fenomena yang ingin dicarikan solusinya, 2) Perumusan hipotesis, 3) Eksperimen, 4) Pengumpulan data, dan 5) Pengambilan kesimpulan.

Tahapan ke tiga dari metode saintifik ini yaitu eksperimen merupakan tahapan penting dalam proses pembelajaran sains. Eksperimen merupakan hal yang penting dalam proses pembelajaran. Oleh karena itu, sebagai seorang scientist perlu memahami apa yang dimaksud dengan eksperimen. Eksperimen terjadi baik dalam bidang fisika, biologi, dan kimia. Pada pembahasan ini akan dibahas mengenai perkembangan eksperimen pada bidang fisika.

\section{PEMBAHASAN}

\section{Pengertian Eksperimen}

Bahasa Latin dari eksperimen adalah experiri artinya menguji coba. Eksperimen diartikan sebagai suatu set tindakan dan pengamatan yang dilakukan untuk mengecek atau menguji hipotesis atau mengenali hubungan sebab akibat antara gejala (Hermawan, 2006).
Pengertian lain dari eksperimen adalah suatu program dengan desain terencana untuk menguji hipotesis yang diturunkan dari teori (Firman, 2017). Eksperimen menyediakan bukti-bukti empiris yang mengkonfirmasi atau menyanggah hipotesis. Selain itu, ekperimen merupakan desain penelitian yang di dalamnya peneliti menyelidiki pengaruh terhadap suatu perlakuan (treatment) terhadap sekelompok subyek (Fraenkel \& Wallen, 2006). Jadi pengertian eksperimen adalah program terencana untuk menguji hipotesis dengan menyediakan bukti-bukti empiris terhadap sekelompok subyek.

Eksperimen memiliki keunggulan yaitu membuat siswa terlatih menggunakan metode ilmiah dalam menghadapi segala masalah, sehingga tidak mudah percaya pada sesuatu yang belum pasti kebenarannya (Roestiyah, 2012). Eksperimen juga berguna untuk membuktikan suatu teori. Selain itu, eksperimen berguna untuk mengembangkan sikap eksploratoris tentang sains dan teknologi, suatu sikap dari seseorang ilmuan (Sagala, 2012). Jadi eksperimen sangat berguna karena memberikan pengalaman langsung sehingga dapat mengembangkan sikap berpikir ilmiah.

\section{Perbedaan Teori dan eksperimen}

Berdasarkan pendekatan epistemologis eksperimen adalah sarana yang digunakan untuk membedakan teori lebih akurat dari yang kurang akurat (Mitchell, 2013). Kunci pendekatan epistemologis adalah menganggap komponen utama eksperimen adalah dalam hal kontribusi mereka terhadap deskripsi sebenarnya dari dunia. Terdapat perbedaan antara "pengembangan teori" dan "pengujian eksperimental". Pada bidang klasik, Karl Popper menjelaskan bahwa eksperimen teori pada dasarnya bertanggung jawab terhadap ilmu pengetahuan, karena mereka mengembangkan teori. Pencoba kemudian diminta untuk menguji dengan cara eksperimen yang didefinisikan dengan baik. Sedangkan yang dimaksud pengembang teori adalah kegiatan menempatkan pertanyaan yang pasti untuk eksperimen.

Pada praktek sains, individu yang sama dapat berfungsi baik sebagai pengembang teori 
dan pencoba. Popper mencoba untuk memperjelas hubungan hirarki tugas-tugas ini. Hasil eksperimen disampaikan kembali ke teori, yang menentukan apakah teori tersebut telah dipalsukan, atau bernilai lebih lanjut. Teori dapat dikatakan salah, jika dalam proses mencari kebenaran tidak berdasarkan hasil observasi dan eksperimen yang dilakukan tanpa percobaan dan kesalahan (Trial and Error) melalui dugaan dan penolakan hanya teori yang paling cocok dapat dipertahankan untuk menghindarkan kesalahan-kesalahan yang pernah dilakukan oleh Neopositivisme, Popper membuat sistem kerja ilmu dengan teori Falsifikasi (Huda, 2007).

Jika menerima pendapat Popper; perbedaan hirarkis antara teori dan eksperimen adalah sebuah teori tetap akan dapat mempertimbangkan beberapa jenis pertanyaan tentang dunia dan masih tetap dalam paradigma dengan cara yang sama. Ekperimentalis cenderung mengabaikan hasil eksperimen jika tidak sesuai dengan paradigma yang ada. Sedangkan Kuhn menyatakan lain terkait perbedaan antara teori dan eksperimen. Menurut Kuhn (2008) menjelaskan bahwa pergeseran dari satu paradigma ke paradigm lain tergantung pada faktor-faktor yang lebih sosiologis daripada epistemologis di alam. Khun mencatat seperti Joseph Priestly dan Lord Kelvin tidak mampu membuat pergeseran ke paradigma yang akhirnya menggantikan proyek penelitian mereka sendiri: Priestley tidak pernah menerima teori oksigen, atau Lord Kelvin mengenai teori elektromagnetik.

Di dalam fisika, ada beberapa teori yang digunakan secara keseluruhan dan bukan di satu bidang saja. Pada wilayah kesahihan tertentu teori diyakini benar adanya. Contohnya, teori mekanika klasik dapat menjelaskan pergerakan benda dengan tepat, asalkan benda ini lebih besar daripada atom dan bergerak dengan kecepatan jauh lebih lambat daripada kecepatan cahaya. Fisikawan yang menganggap teori-teori dasar ini menyimpang hanya sedikit jumlahnya. Oleh karena itu, teori-teori tersebut digunakan sebagai dasar penelitian menuju topik yang lebih khusus, dan semua pelaku Fisika, apa pun spesialisasinya, diharapkan memahami teori-teori tersebut. Teori-teori utama fisika terdiri dari mekanika klasik, elektromagnetik termodinamika, mekanika statistik, mekanika kuantum, dan teori relativitas.

\section{Karakteristik periode sejarah Fisika tentang eksperimen}

\section{a. Periode I (antara zaman purbakala sampai dengan $1500 \mathrm{SM}$ )}

Pada periode ini ditandai dengan belum adanya eksperimen yang sistematis dan kebebasan dalam mengadakan percobaan. percobaan dan eksperimen yang dilakukan pengamatan yang masih sederhana dan tidak sistematis sehingga hasil yang diperoleh kurang memuaskan karena jauh dari ketelitian yang dapat menjamin kebenaran dari teori yang diajukan.

b. Periode II (sekitar tahun 1550 sampai dengan 1800 SM)

Perkembagan ilmu Fisika pada periode ini berdasarkan metoda eksperimen yang dapat dipertanggungjawabkan, diakui dan diterima sebagai persoalan ilmiah. Oleh karena itu periode kedua ini dikenal dengan sebutan "Periode Kebangkitan Metode Eksperimen". Penyelidikan berkembang pesat sekali pada periode ini. Kaidahkaidah, hukum-hukum dan azaz-azaz yang sebelumnya hanya diterima begitu saja, mulai saat itu harus dibuktikan kebenarannya lewat eksperimen. Didalam periode ini muncul penemuan-penemuan yang pada perkembangan berikutnya merupakan dasar yang cukup fundamental, dalam bidang mekanika, optika, juga bidang astronomi (Nur, 2017).

Percobaan-percobaan yang dilakukan oleh Galilei (1564-1642) mengemukakan pandangan-pandangan modern yang scientific berdasarkan pengamaatan dan percobaan-percobaan. Galilei adalah seorang yang berpengetahuan luas dan sangat teliti. Beliau dipandang sebagai Bapak Fisika Eksperimental. Selain Galilei, tokoh-tokoh pada periode kedua ini adalah: (1) Tycho Brahe (1546-1601) dan Kepler (1571-1630). Tycho adalah seorang peneliti dan pengamat sedangkan Kepler adalah seorang toeritis. Tycho memberikan data yang akurat pada Kepler yang menciptakan 
suatu teori baru tentang gerak planet-planet. Tanpa usaha Kepler menyusun teori, observasi Tycho tersebut tidak akan menarik, dan tidak akan berarti apa-apa. Sebaliknya bagi Kepler, tanpa data akurat dari Tycho, teori-teorinya hanyalah akan tinggal merupakan teori saja. (2) Kircher (1601-1680) dengan eksperimennya yaitu menarik sepotong besi dari kedua kutub suatu magnet. (3) Cabeo (1585-1650) dengan eksperimennya yaitu memperlihatkan bahwa sebuah jarum besi yang tidak mengandung magnet, yang terapung dengan bebas diatas permukaan air, akan terletak sepanjang garis meridian magnet bumi. (4) Gillibrand (1597-1637) menemukan bahwa deklinasi magnet berubah dari abad ke abad. (5) Willebrord Snell (1591-1626) mendapatkan hukum pembiasan cahaya yang sering disebut Hukum Snellius. hukum ini didapat oleh Snell secara eksperimen bukan secara teoritis. (6) Evangelista Torricelli (16081647) membuat alat yang dapat dipergunakan mengukur tekanan udara pada tempat yang berbeda-beda, tetapi dengan tidak sengaja menemukan ruang hampa. (7) Otto Van Guwericke (16021686) membicarakan tentang ruang vacum. Hasil percobaannya membuktikan bunyi tidak terdengar dalam ruang hampa udara. (8) Pascal (1623 - 1662) hasil percobaannya menghasilkan Hukum Pascal.

c. Periode III (Periode singkat, 1800 sampai dengan 1890)

Pada periode ini perkembangan lebih pesat lagi. Karakteristik pada periode ini adalah kemajuan pesat dari pertumbuhan dan perkembangan Fisika klasik yang meletakkan dasar Fisika kuantum yang terkenal diabad sekarang ini. Pada tahun 1880 tidak sedikit ahli Fisika yang percaya bahwa hukum-hukum Fisika yang terpenting telah ditemukan. Periode ini diwarnai hukum-hukum gerak Newton dan transformasi Galileo, yang terpenting adalah ditemukannya persamaan Hamiltonian. Persamaan Hamiltonian merupakan bentuk baru dari persamaan gerak. Pada periode berikutnya, persamaan Hamiltonian sangat sesuai dengan persamaan gerak mekanika gelombang Schrodinger dikenal dengan operator Hamilton yang sangat berguna dalam memecahkan persoalan teoritis.

Selain persamaan Hamiltonian, terjadi juga pengembangan pada bidang optik, dan penemuan-penemuan tentang listrik magnet. Bidang optik ini ditandai dengan adanya penerapan pada teori gelombang terhadap teori emisi Newton. Penemuanpenemuan tentang listrik magnet mempunyai peranan dalam kehidupan manusia sehari-hari.

Pengamatan dan percobaan pada bidang optik tokohnya adalah Thomas Young pada tahun 1802 menghidupkan kembali teori gelombang cahaya Huygens dan menyatakan bahwa terpecahnya berkas cahaya di bidang batas antara dua medium, menjadi berkas cahaya refraksi. Hal ini tidak dapat di jelaskan secara memuaskan oleh teori emisi Newton. Thomas Young mengusulkan prinsip interferensi dari dua gelombang sebagai keterangan dari cincin newton dan warna dari plat-plat tipis. Kesimpulannya Thomas Young telah dapat membuktikan interferensi dua berkas cahaya yang mengakibatkan kemenangan bagi teori gelombang cahaya Huygens dari teori Corpuscular Newton. Selain itu, pada bidang listrik magnet hasil penelitian Galvani, Volta, Oersted, Biot Savart, Ampere, Faraday, Lorentz dan Thomas Alfa Edison, yang memberikan dasar kebenaran Teori Elektomagnetik Maxwell pada periode tersebut.

\section{d. Periode IV (tahun 1887 sampai dengan} 1925)

Pada periode ini telah berkembang dari periode sebelumnya karena fenomena yang diteliti lebih mikroskopis. Konsep-konsep Fisika yang berdasarkan hukum-hukum Newton tidak bisa lagi digunakan untuk menjelaskan hasil eksperimen sehingga diperlukan konsep baru yang tidak sama dengan konsep fisika klasik (Suparmi, 2011). Teori-teori kuantum muncul di periode ini. Pengembangan konsep baru ini adalah hasil kerja sama yang sangat 
mengagumkan antara dugaan yang radikal yang diusulkan oleh kelompok teoritis dengan eksperimen yang brilian dan dilakukan oleh kelompok eksperimen.

Karakteristik pada periode ini ditandai dengan adanya fenomena-fenomena mikroskopis. Fenomena mikroskopis yaitu fenomena yang tidak dapat dilihat langsung, seperti elektron, neutron dan sebagainya. Fenomena mikroskopis mendorong munculnya Fisika Kuantum untuk dapat menjelaskan fenomena tersebut yang tidak dapat dijelaskan berdasarkan hukum Newton. Efek fotolistrik, kemudian Sinar X (1895), Radioaktivitas (1896) dan Elektron (1900) muncul pada juga muncul pada periode ini. Efek fotolistrik adalah peristiwa terlemparnya elektron dari permukaan logam yang disinari dengan cahaya (Suparmi, 2011). Eksperimen efek fotolistrik dilakukan oleh Philipp Lenard menunjukkan bahwa energi elektron yang terlempar dari permukaan logam ditentukan oleh frekuensi radiasi yang jatuh ke logam.

Teori kuantum yang muncul ini masih dihubung-hubungkan dengan teori klasik semi modern, karena itu perkembangannya kurang pesat. Periode ini disebut juga "Teori kuantum mekanika lama (The Old Quantum Mechanics)". Teori kuantum mekanik lama didasari oleh konsep dualisme, yaitu partikel sebagai gelombang dan gelombang sebagai partikel.

\section{e. Periode V (Tahun 1925 sampai sekarang)}

Fisika klasik tidak dapat menerangkan fenomena-fenomena mikroskopis seperti elektron, neutron yang ditemukan pada periode sebelumnya. Pada tahun 1925 dimulai perkembangan baru menghasilkan teori yang lebih revolusioner tidak mengindahkan mekanika klasik. Teori baru ini dikenal dengan "Teori Kuantum Mekanika Baru (The New Quantum Mechanics)". Teori baru tersebut muncul berdasarkan uraianuraian teoritis dari De Broglie, Heisenbergh dan Schrodinger serta percobaanpercobaan Davision dan Germer dari G.R. Thomson. Teori kuantum baru dilandasi oleh persamaan Schrodinger untuk menentukan energi partikel atau elektron. Fungsi gelombang digunakan untuk mempresentasikan dinamika partikel yang bergerak yang diperoleh dari penyelesaian Persamaan Schrodinger dari partikel tersebut. Persamaan Schrodinger memainkan peran yang secara logika analog dengan pernyataan hukum II Newton (Suparmi, 2011).

\section{Filsuf yang terkenal dalam mengembangkan dan mempraktekkan percobaan \\ a) Francis Bacon (1561-1626)}

Francis Bacon merupakan pencetus pemikiran empirisme yang mendasari sains hingga saat ini (Buckingham, et al, 2010). "Metode Bacon" merupakan tulisan dan pemikirannya mempengaruhi metodologi sains yang menitikberatkan pada eksperimen. Bacon melakukan suatu percobaan untuk mengawetkan makanan dengan menggunakan salju.

Kuhn (2008) menjelaskan dua tradisi yang berbeda dalam perkembangan ilmuilmu. Tradisi pertama yaitu ilmu-ilmu klasik (matematika, astronomi, harmonik, optik, dan statika), telah sangat berkembang sejak jaman dahulu. IImu ini kemudian berubah pada abad keenam belas dan ketujuh belas. Eksperimen memainkan peran kecil dalam transformasi tersebut. Tradisi kedua, ditandai dengan peran eksperimentasi. IImu-ilmu Bacon yang muncul pada abad ketujuh belas, menyelidiki listrik, magnetik, kimia, dan fenomena panas.

b) Galileo Galilei (1564-1642)

Galileo galilei adalah orang yang pertama kali memperkenalkan proses eksperimen sebagai pusat dari ilmu pengetahuan alam. Terobosannya menghubungkan teori dan eksperimen telah mempengaruhi cara berfikir ilmuan-ilmuan berikutnya. Kerja yang dilakukan Galileo pada benda-benda jatuh bebas. Dari pengamatan dapat disimpulkan bahwa benda-benda berat jatuh dengan cara yang sama seperti benda-benda ringan.

Galileo memainkan peran utama dalam revolusi ilmiah dari abad ketujuh belas. kontribusi untuk astronomi observasional termasuk konfirmasi teleskopik dari fasefase Venus, penemuan dari empat satelit 
terbesar Jupiter (bernama Galilea bulan untuk menghormatinya), dan observasi dan analisis bintik matahari. Galileo juga bekerja di ilmu terapan dan teknologi, menciptakan kompas militer ditingkatkan dan instrumen lainnya.

\section{c) Robert Boyle (1627-1691)}

Robert boyle dengan eksperimennya dengan pompa vakum menunjukkan bahwa pengamatan benda jatuh tepat benar untuk benda-benda jatuh tanpa adanya hambatan dari gesekan udara. Pada akhir abad ke tujuh belas mengembangkan termodinamika. Selain mekanika klasik dan termodinamika, bidang lain yang besar dari pertanyaan percobaan dalam fisika adalah sifat listrik. Pengamatan ini juga mendirikan pemahaman dasar kita muatan listrik dan arus.

d) Isaac Newton (1642-1727)

Percobaan fisika dianggap telah mencapai titik tinggi dengan penerbitan Philosophiae Naturalis Principia Mathematica pada tahun 1687 oleh Sir Isaac Newton (1643-1727). Newton Principia merumuskan hukum gerak dan gravitasi universal yang mendominasi pandangan para ilmuwan dari alam semesta fisik selama tiga abad berikutnya. Newton juga membangun teleskop refleksi praktis pertama dan mengembangkan teori canggih warna berdasarkan pengamatan bahwa sebuah prisma terurai cahaya putih menjadi warna-warna dari spektrum yang terlihat.

\section{PENUTUP}

Eksperimen harus ditunjang inovasi tiada henti karena kemajuan peradaban terus bergulir. Sebagai penemu tidak terkait dengan orang lain, maka ketenaran akan mudah diperoleh. Hasil eksperimen atau percobaan sudah banyak, hanya saja tidak di publikasikan semua. Dipublikasikan atau tidak, yang jelas hasil eksperimen telah merubah kehidupan umat manusia kearah yang lebih produktif. Eksperimen diartikan sebagai program terencana untuk menguji hipotesis dengan menyediakan bukti-bukti empiris terhadap sekelompok subyek.
Menurut Karl popper eksperimen pada dasarnya bertanggung jawab terhadap ilmu pengetahuan, karena mereka mengembangkan teori, pencoba kemudian diminta untuk menguji dengan cara eksperimen yang didefinisikan dengan baik. Sedangkan pengembang teori menempatkan pertanyaan yang pasti tertentu untuk eksperimen. Ekperimentalis cenderung mengabaikan hasil eksperimen jika tidak sesuai dengan paradigma yang ada. Teori tetap akan dapat mempertimbangkan beberapa jenis pertanyaan tentang dunia dan masih tetap dalam paradigma dengan cara yang sama. Sedangkan Kuhn menjelaskan bahwa pergeseran dari satu paradigma ke paradigm lain tergantung pada faktor-faktor yang lebih sosiologis daripada epistemologis di alam.

Periode sejarah Fisika terdiri dari periode satu hingga periode lima. Masing-masing periode mempunyai karakteristik. Pada periode satu ditandai dengan belum adanya eksperimen yang sistematis dan kebebasan dalam mengadakan percobaan. Metode eksperimen berkembang pesat pada periode kedua. Metode ilmiah pada periode dua ditandai dapat dipertanggungjawabkan, diakui dan diterima sebagai persoalan ilmiah. Periode ketiga ditandai dengan perkembangan penyelidikan semakin yang semakin pesat. Pertumbuhan dan perkembangan Fisika Klasik yang meletakkan dasar Fisika Kuantum yang terkenal diabad sekarang. Periode keempat ditandai dengan adanya tinjauan fenomenafenomena mikroskopis yaitu fenomena yang tidak dapat dilihat langsung disebut juga periode The Old Quantum Mechanics yang didasari oleh konsep dualisme. Periode kelima dikenal dengan Teori baru "Teori Kuantum Mekanika Baru (The New Quantum Mechanics)" muncul berdasarkan uraian-uraian teoritis dari De Broglie, Heisenbergh dan Schrodinger.

\section{UCAPAN TERIMAKASIH}

Ucapan terimakasih ditujukan kepada Dr. Harry Firman, M.Pd yang telah membantu mengoreksi dan memberikan saran perbaikan 


\section{DAFTAR PUSTAKA}

Buckingham, W., Burnham, D., Hill, C., King, P.J., Marenbon, J., \& Weeks, M. (2010). The philosophy book. New York: DK Publishing.

Firman, H. (2017). Hakikat sains. Bahan Ajar Filsafat IImu. Bandung: SPs UPI.

Fisher, R. B. (1975). Science, Man and Society. Toronto: Saunders Company.

Fraenkel, J.R., \& Wallen, N.E. (2006). How to design and evaluate research in education. New York: McGraw-Hill.

Herlanti, Y. (2014). Tanya Jawab Seputar Penelitian Pendidikan Sains. Jakarta: Universitas Syarif Hidayatulah.

Hermawan, A. (2006). Penelitian bisnis paradigma kuantitatif. Jakarta: Grasindo.

Huda, M. S. (2007). Karl Raimund Popper: Problem Neopositivistik dan Teori Kritis Falsifikasi. Journal Islamica. 2 (1): 7180.

Jalius. (2011). Munculnya Eksperimen. [Online]. Retrieved 1 oktober 2017 from https://goo.gl/aQWX1O.

Kuhn, T. S. (2008). The Structure Of Scientific Revolution, Peran Paradigma dalam Revolusi Sains. Bandung: PT. Remaja Rosdakarya.

Mitchell, R. (2013) Experimental Life Vitalism in Romantic Science and Literature. Baltimore: Johns Hopkins University Press

Nur, F. (2017). Perkembangan Metode Eksperimen dan Fisika Klasik beserta Tokoh-Tokohnya. [Online]. Retrieved 1 oktober 2017 from https://goo.gl/kVlol8.

Roestiyah, N. K. (2012). Strategi Belajar Mengajar. Jakarta: Rineka Cipta.

Sagala, S. (2012). Konsep dan Makna Pembelajaran. Bandung: Alfabeta.

Suparmi. (2011). Mekanika kuantum I. Surakarta: Jurusan Fisika Fakultas MIPA 